\title{
Community College Transfer Students' Probabilities of Baccalaureate Receipt as a Function of their Prevalence in Four-Year Colleges and Departments
}

\author{
Andrew W. Nutting \\ Hamilton College \\ 198 College Hill Road \\ Clinton, NY 13323 \\ Telephone: (315) 859-4527 \\ FAX: (315) 859-4477 \\ anutting@hamilton.edu \\ April 2008
}

\begin{abstract}
I determine whether community college transfer students have higher baccalaureate rates when they enroll in four-year colleges and departments that have larger shares of transfer students. Transfers attending non-technical campuses with larger shares of transfers have higher eight-year baccalaureate rates, but withincampus increases in share transfers do not increase transfer graduation rates. Transfers in departments with large shares of transfer students have significantly lower graduation rates, but natives in such departments do not. Within-department increases in transfer student presence are positively correlated with transfer eight-year graduation rates and negatively correlated with native eight-year graduation rates, indicating an opportunity for efficiency gains if influxes of transfers are separated from natives.
\end{abstract}

ACKNOWLEDGEMENTS - Thanks to Ronald G. Ehrenberg, Robert Hutchens, George Jakubson, John Porter, Gary Blose, and anonymous referees for suggestions regarding earlier drafts. Thanks to the SUNY Office of Institutional Research and Pinky Chandra for access to data. All remaining errors are my own. 


\section{Introduction}

A critical purpose of two-year colleges, which have enrolled an increasing share of American college students in recent decades, ${ }^{1}$ is the preparation of students for baccalaureate study at four-year colleges. This "transfer function" was the original purpose of two-year colleges (Kane and Rouse 1999). Recent research suggests that over one-third of students who ever enroll in community colleges later attend a fouryear college (Adelman 2004).

The transfer function contains two different components. The first is two-year colleges’ production of students who transfer to four-year colleges (e.g. Velez and Javalgi 1987, Surette 2001, and Alfonso, Bailey, and Scott 2005). The second, which this paper deals with, is the post-transfer performance of transfers at four-year colleges. Most research regarding post-transfer performance has examined transfer graduation rates relative to those of native (non-community-college-transfer) students. In the 1970s many studies by educational researchers and administrators found that transfers graduate at the same rate as natives with similar grades (Hilmer 1997). A more recent paper (Lee, Mackie-Lewis, and Marks 1993) found that transfer students graduate at rates statistically similar to those of comparable native students. Nutting (2004), though, found that transfers have significantly lower graduation rates than natives at the same point in their higher education careers.

This paper examines whether a particular four-year campus-level characteristic is correlated with the rate at which community college transfers earn baccalaureates.

\footnotetext{
${ }^{1}$ According to the 2007 Digest of Economic Statistics (Table 177), in Fall 200547.5 percent of students in public degree-granting institutions were enrolled in community colleges. In 1970, the number was only 34.1 percent.
} 
It uses peer-effects analysis common in the economics of education literature (e.g. Summers and Wolfe 1977; Hanushek 1986; Hoxby 2000; Hanushek et al 2001; Hanushek, Kain, and Rivkin 2002; Vigdor and Nechyba 2004; Cipollone and Rosolia 2007) to examine whether transfers who attend four-year colleges and departments with larger shares of community college transfer students have higher graduation rates. It does not go so far as to interpret its results as identifying a causal relationship between the presence of transfers and transfer graduation rates, though. ${ }^{2}$ Instead it attributes relationships between transfer student presence and transfer student success to unobservable institutional characteristics. For example, assume that some campuses specialize in transfer education by having institutions that assist transfers in the transition from community college to four-year college. At these campuses, transfers would have relatively high graduation rates, and simultaneously a large number of transfers would be attracted to these campuses because of their transferfriendly programs. The presence of transfers would not cause other transfers to have high graduation rates, but the correlation between transfer presence and transfer graduation rates would reflect an important institutional relationship.

Determining whether transfers perform better at campuses and departments with large shares of transfers can extend understanding of the complicated world of public college campus’ accommodation of community college transfers (Handel 2007). Furthermore, the relative growth in the enrollment of two-year colleges (see footnote 1), plus the increase throughout the 1990s in the share of community college

\footnotetext{
${ }^{2}$ Winston and Zimmerman (2003) discuss problems encountered when identifying peer effects among college students. Despite the difficulties, the literature on peer effects in higher education is growing (e.g., Goethals 2000, Sacerdote 2001, Zimmerman 2003, Winston and Zimmerman 2003).
} 
students involved in transfer-oriented academic programs (Nutting 2008, Wellman 2002), means that understanding the transfer process may become especially important in the near future. If there is indeed a relationship between transfer presence and transfer graduation rates, it would also be important information to account for when judging campus-level performance of transfers vis-à-vis state policies and goals (Wellman 2002).

Right now, the only paper the author knows of that examines institutional-level characteristics correlated with graduation rates of community college transfers is Ehrenberg and Smith (2004). That study used grouped data from the State University of New York (SUNY) ${ }^{3}$ and found a statistical similarity between the ranking of SUNY four-year colleges by 1) their graduation rate of community college transfers, and 2) their share of students that were transfers. ${ }^{4}$ This positive relationship between a campus’ presence of transfer students and its transfer graduation rates suggests that some four-year colleges do indeed specialize in the education of transfer students, perhaps by creating institutions to assist in the transition from community college to four-year college. ${ }^{5}$

This paper extends the Ehrenberg and Smith (2004) finding in four critical ways. First, instead of grouped data it utilizes a student-level enrollment dataset from

\footnotetext{
${ }^{3}$ Each grouped observation was of a group of students, matched by four-year college attended, two-year college attended, and type of two-year degree received, if any.

${ }^{4}$ The ranking comparison resulted from estimations that controlled for four-year institutions' six-year baccalaureate rate as a proxy for campus quality. It is worth noting that this particular result was not the primary goal of Ehrenberg and Smith (2004). It is discussed only briefly, immediately preceding the paper's conclusion.

${ }^{5}$ Some evidence suggests that certain campuses cater to transfer students: anecdotal research (e.g. Pappano 2006) has discussed how some colleges are far more likely to accept transfer credits than others, and Cheslock (2005) found that public four-year institutions with higher tuition rates and larger shares of students living off campus have significantly larger shares of transfer students (where transfer students are not limited to community college transfers).
} 
the SUNY Office of Institutional Research that contains numerous individual-student characteristics. Second, it includes information on student field-of-study, allowing analysis to be done at the department level as well as the campus level (department is defined as the intersection of campus and field-of-study). Like campuses, departments that attract numerous transfer students may specialize in educating transfer students. Third, since the dataset follows SUNY students over several years, it allows fixed-effects estimations that control for unobservable campus- and department-level characteristics, such as programs related to transfer-student performance or general quality. This helps identify how changes in transfer presence, a potentially important issue in some university systems (e.g. Perry 2007), are associated with changes in transfer graduation rates.

Fourth, this paper includes results of estimations on native students to determine whether natives and transfers are differently affected by exposure to transfers. If they indeed have different relationships, there are opportunities for efficiency gains (Hoxby 2000). For example, if being surrounded by transfer students increases graduation rates for transfers but decreases them for natives, a university system's counselors and administrators would be advised to separate transfers and natives into different campuses or departments. This would increase the graduation rates of both groups.

This paper's results show that a campus' share of transfer students is significantly positively correlated with transfers’ probability of earning a baccalaureate degree within eight years of initial college enrollment, when not controlling for unobservable campus characteristics and when omitting technical- 
college transfers from the estimations. Results controlling for unobservable campus quality show no positive relationship, though, suggesting that while campuses with large shares of transfers possess characteristics correlated with higher transfer student graduation rates, increases in the presence of transfers do not improve the performances of transfers.

At the department level, conditional on four-year campus and field-of-study, transfers are disproportionately enrolled in departments where they are significantly less likely to earn baccalaureates. This suggests that transfer-heavy departments are of low quality. Within-department increases in share transfer, though, significantly increase transfer student eight-year graduation rates, indicating that departments improve transfer accommodation when there is a temporary influx of transfers.

Note that while some transfer-heavy campuses have higher transfer eight-year graduation rates, transfer graduation rates do not improve when there is a withincampus influx of transfer students. Transfer-heavy departments, on the other hand, tend to graduate transfers at low rates (controlling for campus and field-of-study), but improve their accommodation of transfers when there are temporary increases in their shares of transfers. This suggests that campus-level and department-level institutions respond very differently to the presence of transfer students.

Native students that are enrolled in departments with large shares of transfer students do not have significantly different graduation rates than other natives. But within-department increases in share transfer, which increase transfer graduation rates, reduce native graduation rates. This asymmetry presents an opportunity for efficiency 
gains, and graduation rates of both groups could improve if large influxes of transfers are kept isolated from natives.

The rest of this paper is organized as follows: Section II describes the data set and defines terms of analysis. Section III discusses the estimation strategy and Section IV details results. Section V concludes.

\section{Data}

SUNY consists of 64 campuses: four University Centers (which award doctorates), thirteen University Colleges (which award baccalaureates but not doctorates), thirty community colleges, five specialized colleges of technology awarding baccalaureate and advanced degrees, five colleges of technology awarding two-year degrees, two health science centers, and five statutory colleges located on private college campuses. For students enrolled at SUNY's 64 campuses, the SUNY Student Data File (SDF) records in each semester the student's two-digit field-ofstudy, enrollment status (full- or part-time), number of classes taken, number of credits attempted, credits accumulated from previous semesters, and cumulative grade point average (GPA). It also records demographic information, namely race, gender, and date of birth. The SUNY Degree Historical File (DHF) records the field-of-study, GPA, degree type (BA, BS, AOS, etc) and date of each SUNY degree awarded, and can be matched to the SDF.

This paper analyzes SUNY students who were first-time college students ${ }^{6}$ in a fall semester from 1990 to 1996, who are followed through the Spring 2002 semester.

\footnotetext{
${ }^{6}$ First-time students are students whose variable "higher education history" records them as first-time students. I use SUNY's Term Historic File to eliminate students who were enrolled in SUNY prior to 1990 from my dataset.
} 
From this group, rising juniors—students beginning the first semester of their junior year at a university center, university college, or baccalaureate-granting college of technology—are analyzed. ${ }^{7}$ Since transfers from community colleges ${ }^{8}$ have completed the equivalent of two years of a four-year college education upon enrolling in a four-year college, a transfer's peer group consists of first-semester juniors, i.e. rising juniors. Rising juniors are defined as students who either

a) enter the semester having accumulated between 58 and 75 credits toward a baccalaureate degree (this includes students who attended either a four-year college or a two-year college in the previous semester), ${ }^{9}$ or

b) are new to four-year college and have earned an Associate of Arts (AA) or Associate of Science (AS) degree from a SUNY two-year college. ${ }^{10}$ (These categories are not mutually exclusive.) Students fulfilling the definition of rising junior in multiple semesters are only labeled as such the chronologically first semester they meet the definition. Students who take more than five years from their initial enrollment to become rising juniors are dropped from the analysis.

\footnotetext{
${ }^{7}$ One university college and one baccalaureate-granting college of technology are removed from the sample. Empire State College is a university college that specializes in nontraditional adult education. The SUNY Institute of Technology was, at the time of this study, restricted to upper-division students (juniors and seniors).

${ }^{8}$ Use of the term "community college" means "community college or two-year college of technology" unless otherwise specified.

${ }^{9}$ There is often a lag in time before certain SUNY campuses record credits accumulated after a student transfers. Therefore, I create two variables. Variable A is the future semester's credits accumulated statistic minus the present semester's credits attempted statistic. Variable B is the credits accumulated from the present semester, as recorded in the Student Data File. Students at four-year college whose maximum value of Variable A or B is between 58 and 75 are designated as rising juniors.

${ }^{10}$ Together, AA and AS degrees are commonly called "academic degrees," designed for students who intend to enroll at a four-year college after finishing a two-year college program. The Associate of Applied Sciences (AAS) and Associate of Occupational Sciences (AOS) degrees are frequently called "occupational" degrees and are designed for immediate labor market entrants.
} 
Rising juniors are divided into four groups based on transfer status. The largest group consists of "natives," i.e. rising juniors who have never attended a community college. There are three groups of transfers. "Four-term" transfers spend at least four semesters—-two years—at a community college before transferring "up" to a four-year college. "Early" transfers spend one to three semesters at a community college before transferring up. "Down-and-up” transfers first enroll in higher education at a four-year college, then transfer "down" to a community college, and then back “up” to a four-year college before achieving rising junior status.

Four-term transfers account for 23.6 percent and natives 66.9 percent of rising juniors in the sample. ${ }^{11}$ Table 1 shows summary statistics for four-term transfers and natives. (Appendix Table 1 defines all academic-related variables.) Eighty-six percent of rising junior natives earn baccalaureate degrees within six years of their first-time enrollment in SUNY, compared to less than 60 percent of four-term transfers. Natives have a 0.7-years-shorter time-to-rising junior (the time between a student’s first term in college and his rising junior term, measured in half-year increments) and achieve rising junior status at a much lower age. Women and racial minorities are more prevalent among natives than four-term transfers. ${ }^{12}$ About one-third of transfers have earned AA degrees and over three-quarters have earned some form of associate's degree. Four-term transfers attend a four-year college that averages 77.4 miles from

\footnotetext{
${ }^{11}$ Early transfers and down-and-up transfers respectively are 6.4 percent and 3.1 percent of the sample. ${ }^{12}$ Nationwide, Hispanic presence in community college is relatively high. Calculations from the 2005 Digest of Education Statistics (Table 206) show that in 2004 Hispanics accounted for 8.3\% of public four-year enrollment but $14.2 \%$ of public two-year enrollment. That their numbers are not especially large in SUNY is not surprising, though. Cameron and Heckman (2001) remark that large Hispanic enrollment in community colleges is a function of large Hispanic presences in states, specifically California and Texas, with large and inexpensive community college systems. The City University of New York (CUNY), a separate institution from SUNY, also has a large share of Hispanic students (Leinbach \& Bailey 2006).
} 
their community college, and 56 percent attend the four-year college closest to their community college. $^{13}$

Almost 1 in 10 natives are "lateral transfers"-they transfer from one SUNY four-year college to another before becoming rising juniors. ${ }^{14}$ A vast majority of both natives and four-term transfers are fulltime students, and enrolled fulltime in their first semester of postsecondary education (i.e., their "First-time Fulltime" dummy is equal to 1). Mean GPAs and credits accumulated for the two groups are fairly similar. ${ }^{15}$ For each student, I calculate exposure rates to four-term transfers, early transfers, and down-and-up transfers at both the campus and department level, where department is defined as the intersection of campus and field-of-study. Campus-level (department-level) exposure rate is defined as the percentage of the other rising juniors in the sample at a student's campus (department) that are of a particular group of transfers, e.g. four-term transfers, early transfers, or down-and-up transfers. ${ }^{16}$ Table 1's exposure rate values require elaboration. Figure 1a shows sample distributions of time-to-rising-junior for natives and four-term transfers. The majority

\footnotetext{
${ }^{13}$ I set this indicator variable to 1 if the transfer student attends a four-year college that is either the closest one to his community college or is no more than ten miles farther than the closest one. Some SUNY four-year campuses - for example the University at Buffalo and Buffalo State College-are close together and can attract local transfers from the same two-year campus.

${ }^{14}$ The "lateral transfer" control is actually a linear control for number of lateral transfers, i.e. it is not a dummy variable. The overwhelming majority of lateral transfers (91.6 percent of natives and 99.6 percent of four-term transfers) have laterally transferred once. "Lateral transfers" include transferring from one two-year college to another.

${ }^{15}$ Five of the sixteen four-year campuses do not record student GPA at individual semesters. Additionally, the SUNY system as a whole often does not record GPA the first semester after a student's transfer. Therefore, defining GPA at rising junior term is somewhat difficult. I use the following definitions: if a student earns an associate's degree in his last term before his first-term junior term, I use his associate's degree GPA, which is supplied in the Degree Historical File. In all other cases, I use the GPA at the first-term junior term, taken from the SDF, if available.

${ }^{16}$ The term "department" is not fully accurate, because the field-of-study variable in the SDF is broad. For example, sociology majors and economics majors attending the same campus are, in this paper, assigned to the same "social science" department.
} 
of natives and the plurality of four-term transfers achieve rising junior status exactly two years (four semesters) after first enrolling in SUNY. But four-term transfers have a greater spread of time-to-rising-junior, so that many students transferring from community college take 3 years or longer to reach rising junior status. Because the dataset is limited to students who were first-time students in a fall semester from 1990 to 1996, and because four-term transfers have longer time-to-rising-junior values than natives, a specific academic year's exposure rates may not accurately reflect the transfer/native composition of a rising junior's peers. Figure 1b shows that students who become rising juniors in fairly early years of the sample-academic year 1993, for example, where academic year refers to the calendar year of the spring semesterhave sample peer compositions that overstate their exposure to native students, because many of the transfer students who were rising juniors in 1993 began their college careers before fall 1990. Students who become rising juniors in late years2000, for example - have peer compositions that overstate their exposure to transfer students, because many of the native rising juniors in 2000 began their college careers after fall 1996.

To account for this discrepancy, I create two sets of exposure rates: one "full sample” set and one "academic year" set. Full-sample exposure rates treat the share of four-term transfers at a four-year college (department) as constant over time. Each student's campus-level (department-level) exposure to four-term transfers is calculated as the share of his college's (department's) other rising juniors over the entire sample that are four-term transfers. Academic-year exposure rates separate campuses and 
departments by academic year and calculate exposure rates based on these populations.

Exposure rate values in Table 1 are full-sample exposure rates. The average rising junior native attends a college where 22 percent of rising juniors are four-term transfers, 6 percent are early transfers, and 3 percent are down-and-up transfers. His department-level exposure to four-term transfers is slightly lower than his campuslevel exposure, indicating that natives and four-term transfers congregate in different fields-of-study. Four-term transfers are substantially more exposed than natives to transfer students at both the campus and department levels. Over 30 percent of a fourterm transfer's departmental peers are other four-term transfers.

Table 2 shows field-of-study distributions for four-term transfers and natives. Natives and four-term transfers have generally similar distributions of majors, though transfers are overrepresented in Education and Public Services. The top five majors (one of them being “No Major Declared”) are the same for both groups, though their orders differ. $^{17}$

Unfortunately, the SDF does not follow students outside of the SUNY system. Students who transfer to private or out-of-state colleges are registered as noncontinuers, for example. Wellman (2002) estimates that 30 percent of students who transfer from a New York State public institution do so to either an out-of-state public

\footnotetext{
${ }^{17}$ Two categories of rising juniors have no major chosen: those fully enrolled at a four-year campus ("No Major Declared") and nonmatriculated students. Nonmatriculated students, the majority of whom are transfers, account for a very small percentage of first-semester juniors. These two statuses are treated as separate fields-of-study.
} 
school or an in-state private school. ${ }^{18}$ Additionally, due to an irreversible

programming error, seven of the 245 entering cohorts of students at two-year colleges

are unavailable. The Appendix details the imputation of observations for these cohorts

and their weighted inclusion in the estimations.

\section{Estimation Strategy}

Where $i$ is an individual rising junior, $c$ his four-year campus, and $j$ his field-

of-study, the first equation estimated is

$$
Y_{i j c}=\beta_{1} X_{i j c}+\beta_{2} Z_{i j c}+\psi C_{i c}+\gamma_{j}+\lambda G_{c}+\varepsilon_{i j c} .
$$

The dependent variable $Y$ is 1 if a rising junior earns a baccalaureate within six

calendar years of his initial SUNY enrollment and 0 otherwise. ${ }^{19}$ Six-year

baccalaureate is the dependent variable because The College Entrance Examination

Board's Annual Survey of College Standard Research Compilation data file-i.e. the

College Board Data-uses six-year graduation rate as a measure of institutional

quality. $^{20}$ Eight-year baccalaureate is the dependent variable in certain estimations,

because Nutting (2004) found that transfer students have a long right tail in their time-

to-degree distributions: extending the possible time-to-degree from six years to eight

\footnotetext{
${ }^{18}$ Wellman (2002) does not distinguish between SUNY and CUNY, which are different entities. (See also Footnote 12.)

19 The DHF assigns degrees awarded to a particular calendar date, not a particular semester. Therefore I create artificial "semesters" of degrees awarded. Any degree awarded between May and November, inclusively, of year $x$ is said to have been earned after the spring semester of year $x$. Alternatively, any degree awarded between December of year $x$ and April of year $x+1$ is said to have been earned in the fall semester of year $x$. Time-to-degree calculations, which are in half-year increments, are made using these definitions.

${ }^{20}$ Other studies (e.g. Ehrenberg and Zhang 2005) that analyze institution-level graduation rates use sixyear graduation rate as a dependent variable. Additionally, my definition of a six-year baccalaureate is more general than that of the College Board, which defines six-year baccalaureate rate as a college's share of first-time fulltime students that graduate from the same college within six years. The College Board does not count students who transfer away from the institution and earn degrees from other schools, nor does it include students who transfer to the school and earn baccalaureates. The College Board's strict definition of a six-year baccalaureate rate has come under fire for its limitations (e.g. Adelman 2004, Burd 2004).
} 
years increases the observed number of transfer baccalaureate earners by 18.5 percent, but the observed number of native baccalaureate earners by only 2.2 percent.

All estimations control for individual-level demographic variables $X$ (race, age, sex) and academic variables $Z$ (time to rising junior, fulltime status, first-time fulltime status, credits accumulated, GPA, a dummy variable indicating that the student was a rising junior in a fall semester, fixed effects for year of first enrollment in SUNY). There are also controls for type of community college degree received (AA, AS, AAS/AOS, or Certificate), ${ }^{21}$ and the distance from the student's community college to his four-year college. Distance from two-year college to four-year college may be positively correlated with the costs, and thus the expected benefits, of having transferred to a four-year college. A vector of fixed effects controls for the student's two-year campus of attendance. ${ }^{22}$

$C_{i c}$ is a vector of campus-level exposure controls. It includes the share of students at campus $c$, other than $i$, who are four-term transfers, early transfers, and down-and-up transfers. $\gamma_{j}$ is a vector of field-of-study fixed effects. $G_{c}$ is the sixyear graduation rate of incoming freshmen at four-year college $c$. It proxies for campus quality and is treated as constant over the sample. ${ }^{23}$ Because observations are at the individual-student level, but exposure to transfers varies at the four-year campus

\footnotetext{
${ }^{21}$ The two occupational associate's degrees, AAS and AOS, are combined into one dummy variable, because AAS degree recipients outnumber AOS degrees by a ratio of almost 20-to-1.

${ }^{22}$ A rising junior transfer who attended more than one community college is assigned the two-year campus that he attended for the greater number of semesters. If multiple campuses tie in that regard, the student is assigned the last campus attended.

${ }^{23}$ I calculate the first-time fulltime six-year baccalaureate rate by computing the share of first-time fulltime students at a SUNY four-year college in the entire sample that earn a SUNY baccalaureate within six years (see Footnote 20).
} 
level, standard errors in all estimations of Equation (1) are clustered by four-year campus.

Since Equation (1) does not control for within-campus changes in exposure to transfers, values in $C_{i c}$ are full-sample transfer exposure rates. ${ }^{24}$ Equation (1) thus estimates the cross-sectional relationship between exposure to transfers and the probability of baccalaureate receipt. A significantly positive coefficient on exposure to four-term transfers would indicate that transfers who attend four-year colleges with larger transfer student populations have higher graduation rates. It is important to recognize, though, that a positive coefficient on exposure to four-term transfers could reflect omitted variables and endogenous peer selection (Vigdor and Nechyba 2004). Colleges with large shares of transfer students may have unobservable characteristics that both ensure high graduation rates for four-term transfers and also attract large numbers of four-term transfers. Better estimations of the relationship between exposure to transfers and baccalaureate probability entail estimating the relationship between within-campus changes in exposure to transfers and within-campus changes in the probability of baccalaureate receipt. To accomplish this, I estimate an equation that includes a vector of campus-level fixed effects while controlling for academicyear campus-level exposure rates. Where $t$ is academic year, I estimate

$$
Y_{i j c t}=\beta_{1} X_{i j c t}+\beta_{2} Z_{i j c t}+\psi C_{i c t}+\left(\gamma_{j}^{*} \varphi_{t}\right)+\theta_{c}+\kappa_{c} T I M E_{t}+\varepsilon_{i j c t}
$$

\footnotetext{
${ }^{24}$ Estimations include observations whose credits accumulated and/or GPA values are missing. Their values of credits accumulated and GPA are set to zero and a missing value dummy variable is set to 1 . The credit value is included only if a student's assigned credits variable is at least 50 (see Footnote 9). Students who have credits accumulated values below 50 are assigned a "missing credits" dummy variable value of 1 and a credits value of 0 .
} 
where $\varphi_{t}$ is a vector of academic-year fixed effects, $\theta_{c}$ is a vector of four-year campus fixed effects, and $T I M E_{t}$ is a linear time trend. Since the four-year college's six-year graduation rate $G_{c}$ is time-invariant, it is perfectly collinear with $\theta_{c}$ and omitted from Equation (2). The interaction of $\gamma_{j}$ and $\varphi_{t}$ controls for variation over time in the relationship between rising junior field-of-study and probability of baccalaureate receipt. Because of previously-detailed concerns about academic-year exposure rate variables, the coefficient on $T I M E_{t}$ varies by four-year campus and estimations of Equation (2) are limited to students who were rising juniors in the academic years 1995-1998, inclusively. These academic years, as Figure 1b shows, have fairly stable shares of four-term transfer students and native students, and their sample exposure rates are probably more accurate than those of academic years 1993-1994 and 19992001. Equation (2) standard errors are clustered by the intersection of four-year campus and academic year.

I also estimate two equations where department-level exposure to transfers is on the right-hand-side. Equation (3) is

$$
Y_{i j c}=\beta_{1} X_{i j c}+\beta_{2} Z_{i j c}+\psi D_{i j c}+\gamma_{j}+\theta_{c}+\varepsilon_{i j c}
$$

where $D_{i j c}$ is a vector of department-level exposure controls and all other variables are defined as before. The vector of four-year campus fixed effects $\theta_{c}$ captures timeinvariant between-campus differences in transfers' probability of baccalaureate receipt, and the vector of field-of-study fixed effects $\gamma_{j}$ captures time-invariant between-field differences in probability of baccalaureate receipt. $\psi$ represents the relationship between exposure to transfer students in a specific department and a 
student's probability of baccalaureate receipt. Standard errors in all estimations of Equation (3) are clustered by department.

Equation (3) does not control for within-department changes in exposure rates, so $D_{i j c}$ in Equation (3) is the full-sample exposure rate. Departments, like campuses, may possess unobserved characteristics correlated with both exposure to transfers and graduation probabilities. To control for unobserved department-level characteristics and better determine whether within-department changes in exposure to transfers affect probability of baccalaureate, I regress the following equation:

$$
\begin{aligned}
Y_{i j c t}= & \beta_{1} X_{i j c t}+\beta_{2} Z_{i j c t}+\psi D_{i j c t}+ \\
& \left(\gamma_{j}^{*} \varphi_{t}\right)+\left(\theta_{c} * \varphi_{t}\right)+\left(\gamma_{j}^{*} \theta_{c}\right)+\left(\kappa_{j c} T I M E_{t}\right)+\varepsilon_{i j c t} .
\end{aligned}
$$

There are three interactions of fixed effects in Equation (4): one $\left(\gamma_{j}^{*} \varphi_{t}\right)$ interacting field-of-study fixed effects with academic year fixed effects; a second $\left(\theta_{c}^{*} \varphi_{t}\right)$ interacting four-year campus fixed effects with academic year fixed effects; and a third $\left(\gamma_{j}^{*} \theta_{c}\right)$ creating a vector of department fixed effects by interacting field-ofstudy and campus. The coefficient on $\operatorname{TIME}_{t}$ is permitted to vary by department. All estimations of Equation (4) are clustered by the intersection of department and academic year. Like Equation (2), I estimate Equation (4) on observations from academic years 1995-1998, inclusively.

Throughout this paper, I refer to estimations of Equations (1) and (3) as "crosssection" estimations. I refer to estimations of Equations (2) and (4) as "panel” estimations, because they control for unobserved campus-level and department-level quality, respectively, using fixed-effects techniques typical in panel-data analyses. 
The large number of controls in Equation (4) makes nonlinear probit or logit estimations difficult, so all estimations throughout this paper are OLS where the dependent variable is 1 if $i$ graduates and 0 otherwise. All estimations have heteroskedasticity-corrected standard errors.

Equations are estimated separately on the populations of four-term transfers and natives. As Hoxby (2000) explains, if different populations have different peer effects, there may be the potential for efficiency gains via reallocation of students. For example, if transfers benefit from the presence of other transfers via higher graduation rates, but natives suffer from the presence of transfers, university systems may be wise to place influxes of transfers into departments separate from natives. This would increase the overall graduation rate for both groups.

\section{Results}

Throughout this section, I emphasize coefficients on exposure to four-term transfers, because such students constitute the majority of transfers and because early transfers and down-and-up transfers may possess unobserved characteristics correlated with peer selection and probability of baccalaureate receipt. ${ }^{25}$

\section{a. Campus-Level Results}

Table 3 displays results of Equations (1)-(4) when the dependent variable is six-year baccalaureate. Columns 1-3 show results of cross-section campus-level estimations. The coefficient on exposure to four-term transfers at the campus level is small and insignificant when omitting controls for both campus six-year baccalaureate rate and student field-of-study (Column 1). When controlling for four-year campus'

\footnotetext{
${ }^{25}$ Preliminary estimations on the populations of early transfers and down-and-up transfers did not yield interesting results.
} 
six-year graduation rate (Column 2), the coefficient more than triples, but does not approach statistical significance. The increase in the coefficient, though, shows a negative correlation between a college's presence of four-term transfers and its retention and graduation of entering freshmen. ${ }^{26}$ The six-year graduation rate coefficient in Column 2 is itself large and significantly positive, indicating that transfers are more likely to graduate when attending campuses where direct attendees have high graduation rates. Adding field-of-study controls (Column 3) causes the coefficient on exposure to four-term transfers to fall by one-quarter. ${ }^{27}$ Column 4 shows results from the Equation (2) panel estimation that includes campus-level fixed effects. The coefficient on exposure to four-term transfers is large and negative, but statistically insignificant. All told, Table 3 shows no significant evidence of a positive relationship between the share of a campus' students that are transfers and transfer graduation rates.

Table 3 does show that rising junior four-term transfers with AA degrees or AAS/AOS degrees, controlling for credits accumulated and time to rising junior, are less likely than those with no degree to earn six-year baccalaureates. ${ }^{28}$ It also shows that that transfers who attend the four-year college closest to their two-year college have significantly lower graduation rates, and that four-term transfers who become

\footnotetext{
${ }^{26}$ Cheslock (2005) finds that among private colleges, transfers are more prevalent at colleges with higher attrition rates. He presents no significant evidence that transfers are more prevalent at public schools with higher attrition rates, though.

${ }^{27}$ Field-of-study coefficients from Equation (3) are available from the author upon request.

${ }^{28}$ Ehrenberg and Smith (2004) found that transfers without associate's degrees have lower graduation rates and higher dropout rates than those with degrees. However, Ehrenberg and Smith (2004) did not distinguish between early transfers, four-term transfers, and rising juniors. Since my dataset includes only rising juniors, its transfers-without-degrees are a very select group of overall transfers-withoutdegrees. The difference between the results of Ehrenberg and Smith (2004) and those in Table 3 can be explained by, among transfers without two-year degrees, early transfers having higher dropout rates and lower graduation rates than four-term transfers and rising juniors.
} 
rising juniors in a fall semester instead of a spring semester also have lower graduation rates. These results may capture a "conveyer belt” effect. Transfer students who follow the typical institutional process of transfer-enroll fulltime in a community college, earn an AA degree, and transfer to the local four-year college in a fall semester (when the majority of transfers occur, and the four-year campus may be better prepared for new students)—incur a relatively low cost of transferring. Thus they may not necessarily have high expected benefits, i.e. high graduation probabilities, of attending a four-year college. Students incurring high costs of transfer have high expected benefits of transfer, and thus graduate at higher rates. Alternatively, these results may reflect unobserved differences in family income. For example, transfers able to attend farther-away campuses may be from higher-income families, and therefore more likely to earn a baccalaureate. Unfortunately, family income information is unobserved.

Since the large majority of transfer students (95.8\% of four-term transfers in the dataset) move from community colleges to four-year University Colleges or University Centers, it is possible that transfers to or from technology colleges face different hurdles than more traditional transfer students. For example, campus programs designed to smooth the transition to four-year college may better assist transfers from community colleges than those from technology colleges. Table 4a shows coefficients on campus-level exposure to four-term transfers when I drop transfers to and from technology colleges from the sample. The 36 coefficients in Table 4 reflect results from 36 different estimations. Panel A shows results where the dependent variable is six-year baccalaureate and Panel B shows results when it is 
eight-year baccalaureate. All cross-section coefficients control for four-year campus' six-year baccalaureate rate and treat campus-level exposure to transfers as timeinvariant.

Removing technical college transfers from cross-section estimations (Columns 1-2) increases the coefficient on campus-level exposure to four-term transfers. In the eight-year baccalaureate estimations, the coefficient is significantly positive at the $10 \%$ level when omitting transfers both from two-year technical colleges and to fouryear technical colleges (Row 6, Columns 1 and 2). The point estimate suggests that the four-term transfer graduation rate is $3 \%$ higher at a four-year campus with a $10 \%$ higher share of four-term transfers. This indicates that transfer-heavy campuses have higher graduation rates for transfer students in some cases, providing some reaffirmation for the findings of Ehrenberg and Smith (2004).

Columns 3 and 4 of Table 4a reproduce Columns 1 and 2, respectively, but remove "unaffiliated" rising juniors—nonmatriculated students and fulltime students with no declared major—from the sample. Coefficients become much smaller when dropping unaffiliated students, and the eight-year baccalaureate coefficients are rendered insignificant. This suggests that the positive relationship between attending a transfer-heavy campus and graduating accrues primarily to four-term transfers who have not declared a major upon their enrollment in a four-year college.

Columns 5 and 6 display robustness checks of the campus-level panel estimation. Column 5 includes unaffiliated students in the sample and Column 6 omits them. Columns 5 and 6 show no evidence of a positive relationship between the share of transfer students at a four-year campus and a transfer student's probability of 
baccalaureate receipt. Thus the significant positive relationship in Row 6 Columns 12 presumably reflects unobservable campus characteristics that benefit transfersprimarily unaffiliated ones - and are correlated with large shares of transfer students. Campuses with many four-term transfers may possess institutions that take aimless, unaffiliated transfer students and point them towards particular fields-of-study, making them more likely to graduate within eight years.

To recap: there is statistically significant evidence that (non-technical) community college transfers who attend (non-technical) four-year colleges with larger shares of transfer students experience higher eight-year graduation rates. But since coefficients are not positive when campus fixed effects are included, there is no evidence that within-campus increases in share transfer students positively affect transfer graduation rates. The significantly positive relationship in some cross-section estimations thus appears to represent unobservable four-year-campus-level characteristics that both help transfer students graduate and are correlated with a large presence of transfer students.

Additionally, campus fixed-effects estimations on the population of native students yield results (not shown) similar to those of four-term transfers, with all but one coefficient being insignificantly negative. ${ }^{29}$ Thus there is no evidence that fourterm transfers and natives are differently affected by campus-level changes in the presence of transfers.

\footnotetext{
${ }^{29}$ These results are available from the author upon request. I also performed estimations of Equation (1) on the population of native students, and these showed no evidence of a significant relationship between the presence of transfer students and graduation rates of native rising juniors. I could not control for campus quality in these cross-sectional estimations, though, because the control used in Equation (1) to proxy for campus quality (six-year graduation rate of incoming freshmen) is extremely endogenous to the graduation probability of a native rising junior.
} 


\section{b. Department-Level Results}

Table 5 shows coefficients on department-level exposure to four-term transfers (Equations 3 and 4) when the dependent variable is six-year baccalaureate. Crosssection estimations on the population of four-term transfers yield small and insignificant coefficients when omitting field-of-study fixed effects (Columns 1 and 2). Including both campus and field-of-study fixed effects (Column 3), though, shows that a 10-percentage-point higher share of four-term transfers in a department is associated with a significant 1.5-percentage-point lower probability of a four-term transfer earning a six-year baccalaureate. Among natives, cross-section results are significantly positive until field-of-study controls are included (Column 3), at which point the coefficient indicates absolutely no relationship between department-level exposure to transfers and the graduation rate of natives. Department-level panel results for both four-term transfers and natives (Column 4) are insignificant.

Three notes regarding Table 5 are especially interesting. First, that adding controls for field-of-study sharply reduces cross-section coefficients for both four-term transfers and natives suggests that four-term transfers congregate in fields-of-study in which all rising juniors—-transfer and native—-have relatively high six-year graduation rates. Second, Column 3 shows that departments with large shares of transfer students have lower graduation rates for transfer students, but not for native students. This suggests, surprisingly, that departments that attract numerous four-term transfers are of low quality for transfers, but somehow native students are insulated from this low quality. Third, the insignificant panel results suggest that department-level differences 
in transfer graduation rates reflect unobservable quality differences unrelated to the ceteris paribus presence of transfer students.

Table 6a displays department-level coefficient results when omitting technicalcollege transfers from estimations on the population of four-term transfer students. Every coefficient in Table 6a reflects a different estimation, and every estimation includes controls for campus and field-of-study. All cross-sectional coefficients in Columns 1-2 are significantly negative, whether the dependent variable is six-year baccalaureate (Panel A) or eight-year baccalaureate (Panel B), whether including unaffiliated students (Column 1) or omitting them (Column 2), and when removing technical college transfers. Evidence thus strongly suggests that departments with large shares of four-term transfers graduate four-term transfers at lower rates.

Columns 3 and 4 show robustness results of the department-level panel estimation. Every coefficient from the eight-year baccalaureate estimations (Panel B) is significantly positive. Table 6a thus suggests something rather interesting: fourterm transfers in departments that attract numerous transfer students, ceteris paribus, experience lower six-year and eight-year graduation rates, but, controlling for unobservable departmental characteristics such as quality, temporary withindepartment increases in transfer students improve eight-year graduation rates for fourterm transfers.

Recall that for four-term transfers campus-level coefficients were positive in the cross-section but insignificantly negative in the panel. But department-level coefficients are negative in the cross-section but significantly positive with respect to eight-year graduation rates in the panel. That campus-level and department-level 
estimations yield such different results suggests that campus-level institutions and department-level institutions respond differently to changes in the share of transfer students among incoming rising juniors. Campuses may have time-invariant institutions that help relatively aimless community college transfers adjust to four-year college, but those institutions do not change substantially if a college changes its share of transfers in a given year. Departments with many transfers may not, conditional on field-of-study and campus, graduate transfers at high rates, but if transfers form an unusually large share of an incoming class, departments are able to make adjustments to accommodate transfers and ensure them higher baccalaureate probabilities. ${ }^{30}$

Table $6 \mathrm{~b}$ repeats Table 6a for native students. All cross-sectional coefficients (Columns 1 and 2) are insignificant, indicating that natives in departments with large shares of transfer students perform no worse than other natives. But all eight-year baccalaureate panel coefficients are significantly negative, suggesting that, when controlling for unobservable departmental quality, larger shares of four-term transfers hinder graduation rates of natives. Given that Table 6a showed that such influxes of transfers significantly increase graduation rates of four-term transfers, it appears that departments make accommodations to large influxes of transfers, but do so at the expense of their native students. This suggests that directing influxes of four-term transfers towards specific departments and away from native students may, in the short run, improve the graduation rates of both groups.

\footnotetext{
${ }^{30}$ Results from estimations that did not include imputed the missing observations discussed in the Appendix are available from the author upon request. They are consistent with those when including imputed observations, i.e. some campus coefficients are significantly positive in the cross-section and all are insignificantly negative in the panel, and department coefficients are negative in the cross-section and positive in the panel.
} 


\section{Conclusion}

This paper finds that, conditional on campus quality, community college transfer students who attend non-technical four-year colleges that have higher shares of transfer students have significantly higher eight-year baccalaureate rates. The positive relationship appears to especially affect transfers who have not declared majors upon their enrollment in four-year college. There is no evidence that withincampus changes in the number of transfer students increase the probability of a transfer student receiving a baccalaureate degree, though. A plausible hypothesis unifying these findings is that four-year colleges with atypically large shares of transfer students possess unobserved institutions that specialize in transfer student education, and that these institutions especially benefit transfers who have not declared a major when they transfer. (For example, campuses with large shares of transfers may have services that guide students towards fields-of-study in which they can best earn a timely baccalaureate.) But increases in the presence of transfers at a given campus do not spur improvements in these institutions.

Department-level estimations show that, conditional on campus and field-ofstudy, transfer students in departments with large shares of transfer students have significantly lower rates of baccalaureate receipt, even though native students in the same departments do not have lower graduation rates than other natives. However, within-department increases in exposure to transfers significantly positively impact the probability of transfers earning eight-year baccalaureates. That is, departments with high levels of transfers have lower graduation rates for transfers, but departments tend to improve their accommodation of transfers when faced with influxes of transfer 
students. These accommodations come at the cost of native students, who have lower graduation rates when their departments have influxes of transfer students. This may suggest that perhaps large cohorts of transfer students should be isolated from native students as best as possible, which could maximize the graduation rates of both groups.

The findings in this paper suggest opportunities for further research regarding the performance of community college transfer students at four-year colleges. Future studies, for example, could determine whether transfer-heavy public campuses in states other than New York have higher graduation rates for transfers. As Ehrenberg and Smith (2004) and Wellman (2002) detail, different states have much different public higher education systems and transfer policies, and it would be worthwhile to note whether these findings from SUNY are valid in other states. Another useful topic of research would be a "black box" examination of exactly what institutions at fouryear colleges and departments most affect transfer student performance. Though this paper found some evidence that some four-year colleges specialize in transfer education, it could only hypothesize about what particular policies or offices actually positively impacted transfer graduation rates.

\section{APPENDIX}

Due to an irreversible programming error I am missing 7 of 245 entering twoyear college cohorts. Five are from a small community college ("Campus A") and two are from a mid-sized community college (“Campus B”). I possess actual observations from (non-missing) cohorts of these two campuses. 
To impute observations from these cohorts I regress each two-year college's entering cohort size on vectors of campus and year fixed effects and then create predicted values of the sizes of the 7 missing cohorts.

I separate observed rising juniors from Campuses A and B by the intersections of two-year campus, four-year campus, field-of-study, and time to rising junior. I then calculate the share of observed first-time students at Campus A (or B) that ended up in each intersection.

I take these shares and apply them to the imputed sizes of each of the 7 entering cohorts described in the first paragraph of the appendix. For example, if 1.5\% of observed Campus A entrants enrolled in social sciences at SUNY-Albany two years after entering a community college, I assume that $1.5 \%$ of those in each unobserved cohort from Campus A did so as well.

This imputes cell sizes based on four-year campus, two-year campus, field-ofstudy, year of initial SUNY entry, fall semester, and academic year of rising junior term. (Academic year of rising junior term is determined by finding out the rising junior term, which is the student's first term in the sample plus the time it took him to become a rising junior.) Values of other variables used in estimating Equations (1) (4) are determined by the means of the observed intersections (e.g., observed Campus A entrants that enrolled in social sciences at SUNY-Albany two years after entering a community college) that are used to create the imputed cells. Each imputed cell is treated as one observation and it is weighed by its imputed size. The weight is used to weight estimations and to determine exposure rates to transfer students. 


\section{References}

Adelman, C. (2004) Principal Indicators of Student Academic Histories in Postsecondary Education, 1972-2000. Washington, DC: US Department of Education, Institute of Education Sciences.

Alfonso, M., Bailey, T.R. and Scott, M. (2005) “The Educational Outcomes of Occupational Sub-Baccalaureate Students: Evidence from the 1990s.” Economics of Education Review, 24 (2), 197-212.

Burd, S. (2004) “Graduation Rates Called a Poor Measure of Colleges.” The Chronicle of Higher Education, 50:30, p. A1..

Cameron, S. V.; Heckman, J. J. (2001) “The Dynamics of Educational Attainment for Black, Hispanic, and White Males” The Journal of Political Economy, 109:3, pp. 455-99.

Cheslock, J. J. (2005) “Differences between public and private institutions of higher education in the enrollment of transfer students." Economics of Education Review, 24:3, pp. 263-274.

Cipollone, P., and Rosolia, A. (2007) "Social Interactions in High School: Lessons from an Earthquake.” American Economic Review, 97:3, 948-965.

Ehrenberg, R. G. and Smith, C. L. (2004) "Within State Transitions from 2-Year to 4Year Public Institutions.” Economics of Education Review, 23:1, pp. 11-28.

Ehrenberg, R. G. and Zhang, L. (2005) "Do Tenured and Tenure-Track Faculty Matter?” Journal of Human Resources, 40:3, pp. 647-659.

Handel, S.J. (2007) “Transfer Students Apply to College, Too. How Come We Don't Help Them?” The Chronicle of Higher Education, 54:9, p. B20.

Hanushek, E. A. (1986) "The Economics of Schooling: Production and Efficiency in Public Schools.” Journal of Economic Literature, 24:3, pp. 1141-1177.

Hanushek, E. A., Kain, J. F. and Rivkin, S. G. (2002) “New Evidence about Brown v. Board of Education: The Complex Effects of School Racial Composition on Achievement.” NBER Working Paper 8741.

Hanushek, E. A.; Kain, J. F.; Markman, J. M.; and Rivkin , S.G. (2001) “Does Peer Ability Affect Student Achievement?” National Bureau of Economic Research, Inc, NBER Working Paper 8502. 
Hilmer, M. J. (1997) “Does Community College Attendance Provide a Strategic Path to a Higher Quality Education?” Economics of Education Review, 16:1, pp. 59-68.

Hoxby, C. M. (2000) "Peer Effects in the Classroom: Learning from Gender and Race Variation.” NBER Working Paper 7867.

Goethals, G. R. (2000) “Social Comparison and Peer Effects at an Elite College.” Williams Project on the Economics of Higher Education.

Kane, T. J. and Rouse, C. E. (1999) "The Community College: Educating Students at the Margin Between College and Work.” Journal of Economic Perspectives, 13:1, pp. 63-84.

Lee, V. E., Mackie-Lewis, C. and Marks, H. M. (1993) "Persistence to the Baccalaureate Degree for Students who Transfer from Community College.” American Journal of Education, 102:1, pp. 80-114.

Leinbach, D. T., \& Bailey, T.R. (2006) “Access and Achievement of Hispanics and Hispanic Immigrants in the Colleges of the City University of New York.” Community College Research Center, Teacher’s College, Columbia University.

Nutting, A.W. (2004) "Time-of-Transfer and the Outcomes of Attending a Four-Year College: Evidence from SUNY.” Cornell Higher Education Research Institute Working Paper.

Nutting, A.W. (2008) "Costs of Attendance and the Educational Programs of FirstTime Community College Students.” Economics of Education Review, forthcoming.

Pappano, L. (2006) “The Transfer Student Nightmare: Getting Credit Where Credit Is Due." The New York Times, April 23, p. 4A.

Perry, N. (2007) “UW Transfers: A Thorny Issue.” The Seattle Times, March 11, p. B1.

Sacerdote, B. (2001) "Peer Effects With Random Assignment: Results for Dartmouth Roommates.” Quarterly Journal of Economics, 116:2, pp. 681-704.

Summers, A. A. and Wolfe, B. L. (1977) “Do Schools Make a Difference?” American Economic Review, 67:4, pp. 639-652.

Surette, B. J. (2001) “Transfer from two-year to four-year college: an analysis of gender differences.” Economics of Education Review, 20:2, pp. 151-163. 
Velez, W. and Javalgi, R. G. (1987) "Two-Year College to Four-Year College: The Likelihood of Transfer.” American Journal of Education 96:1, pp. 81-94.

Vigdor, J. and Nechyba, T. (2004) “Peer Effects in North Carolina Public Schools.” Working Paper.

Wellman, J. V. (2002) State Policy and Community College-Baccalaureate Transfer. National Center for Public Policy and Higher Education and the Institute for Higher Education Policy.

Winston, G. C. and Zimmerman, D. J. (2003) “Peer Effects in Higher Education.” NBER Working Paper 9501.

Zimmerman, D. J. (2003) "Peer Effects in Academic Outcomes: Evidence from a Natural Experiment.” Review of Economics and Statistics, 85:1, pp. 9-23. 


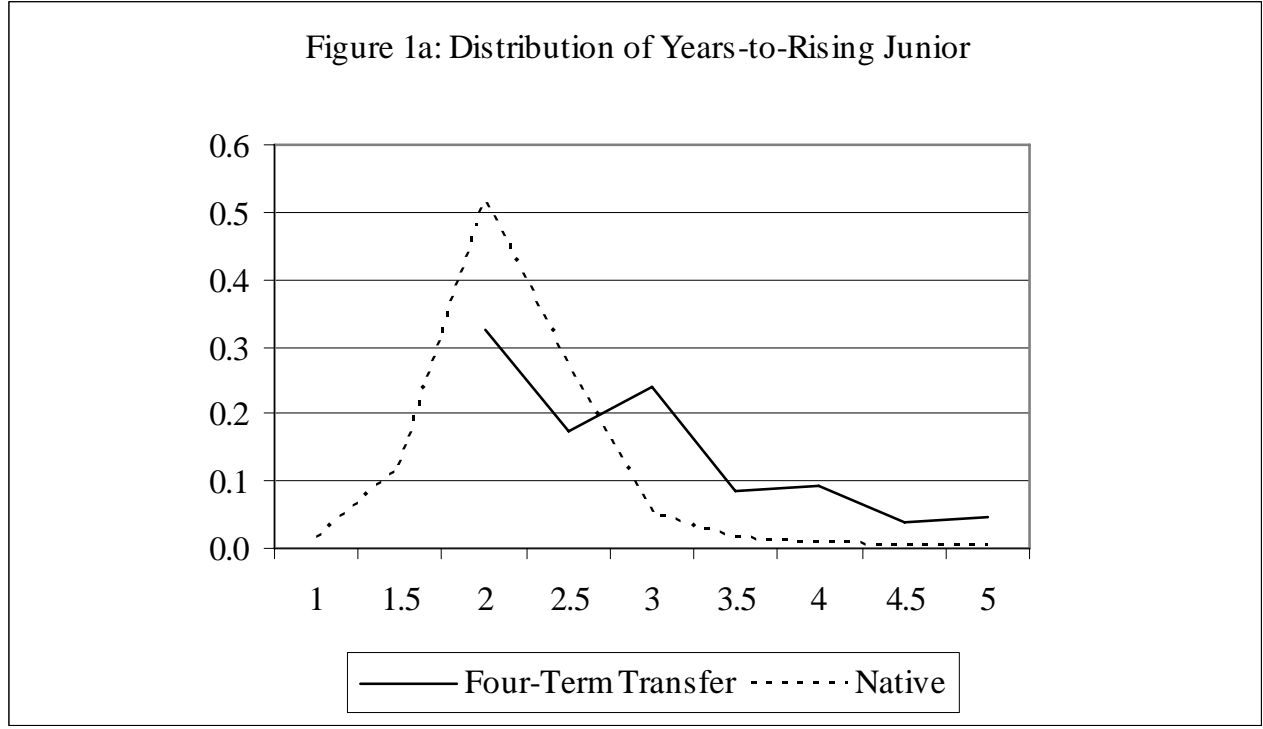

Figure 1b: Share of Rising Juniors, by Transfer Status

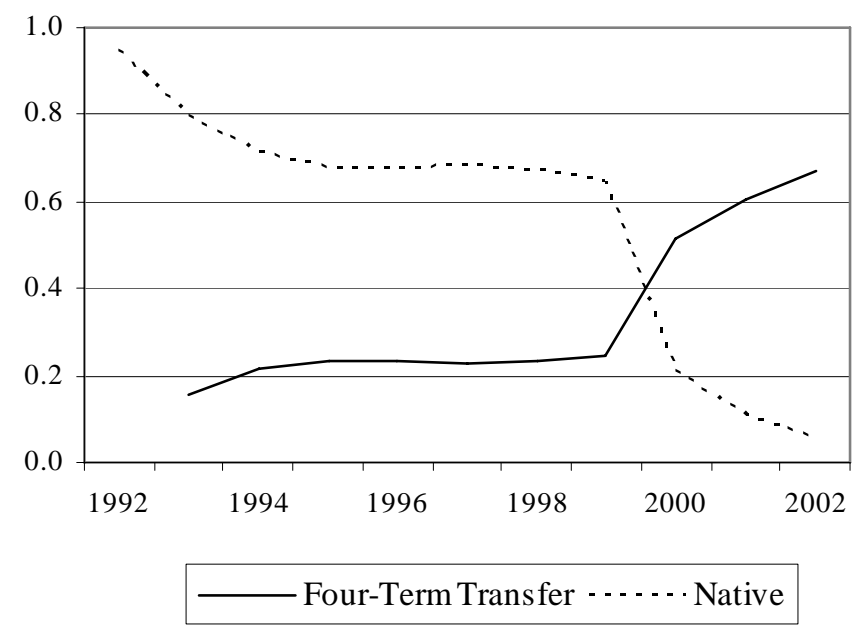


Table 1

Summary Statistics for Rising Juniors

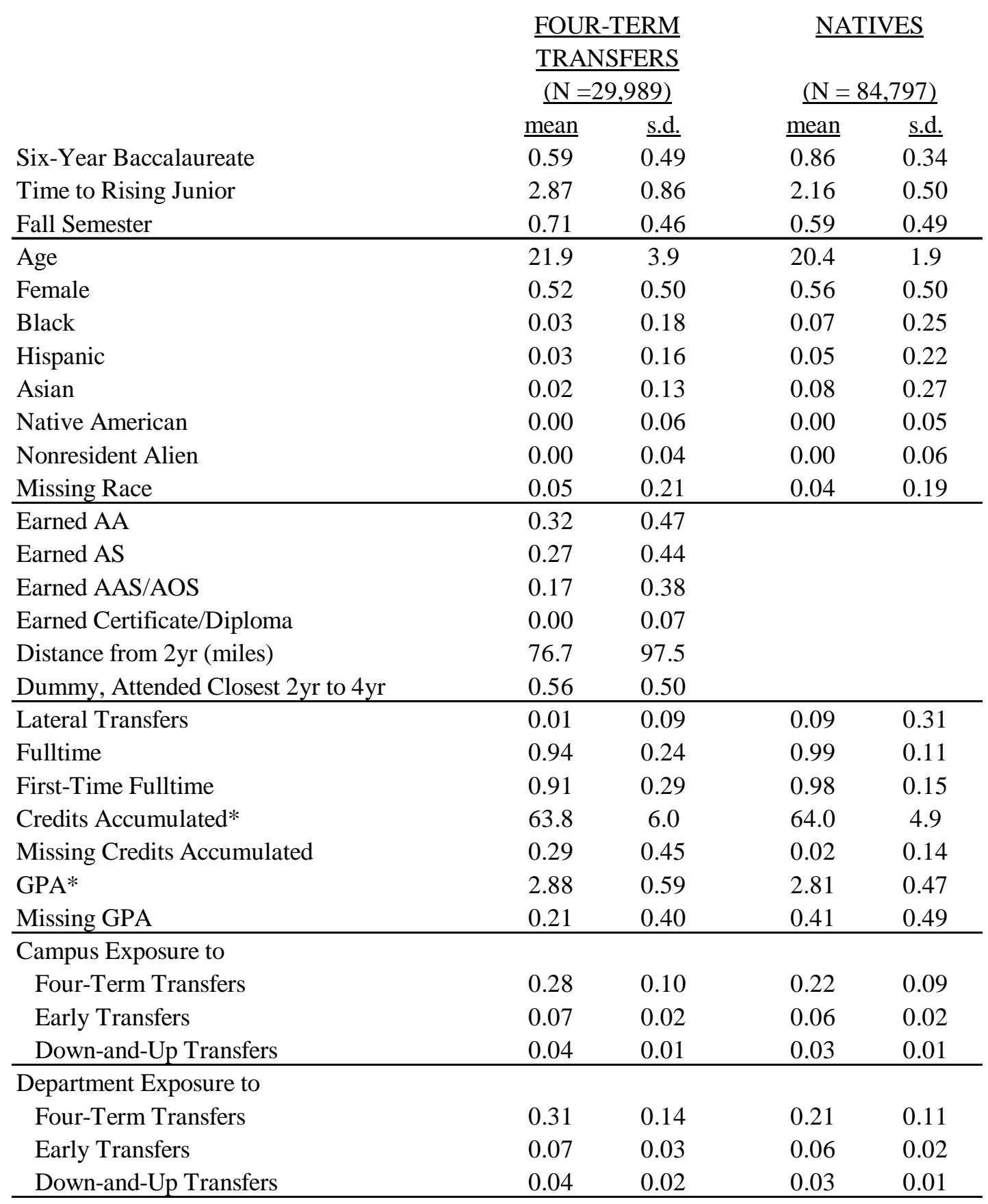

* = Means and Standard Deviations for Credits Accumulated and GPA omit missing values 
Table 2

Field-of-Study Distributions

Education

Social Science

No Major Declared

Business

Humanities

Public Services

Biology

Arts

Mathematics

Engineering

Nonmatriculated

Health Sciences

Physical Sciences

Architecture

Liberal Arts/General Studies

Home Economics

Applied Arts

Agriculture \& Forestry

Veterinary Science
FOUR-TERM NATIVES

TRANSFERS

$(\mathrm{N}=29,989)$

19.9

$\underline{(\mathrm{N}=84,797)}$

19.4

12.9

23.3

$12.5 \quad 15.3$

$11.9 \quad 10.8$

$8.8 \quad 11.4$

$\begin{array}{ll}6.7 & 1.8\end{array}$

$3.5 \quad 6.3$

$3.0 \quad 4.4$

$\begin{array}{ll}2.7 & 3.8\end{array}$

$\begin{array}{ll}1.9 & 1.7\end{array}$

$\begin{array}{ll}1.7 & 0.3\end{array}$

$1.6 \quad 1.8$

$1.3 \quad 2.4$

$1.3 \quad 1.1$

$1.3 \quad 1.2$

$\begin{array}{ll}0.9 & 0.8\end{array}$

$\begin{array}{ll}0.7 & 0.7\end{array}$

$\begin{array}{ll}0.7 & 0.1\end{array}$

$0.0 \quad 0.0$ 
Table 3

Results of Equations (1)-(4)

Dependent Variable: Six-Year Baccalaureate

Robust standard errors

* significant at $10 \%$; ** significant at $5 \%$; *** significant at $1 \%$

\begin{tabular}{|c|c|c|c|c|}
\hline & 1 & 2 & 3 & 4 \\
\hline Campus Exposure to & 0.035 & 0.127 & 0.092 & -0.204 \\
\hline Four-Term Transfers & 0.130 & 0.140 & 0.125 & 0.133 \\
\hline Campus Exposure to & 0.195 & -0.054 & -0.430 & -1.207 \\
\hline Early Transfers & 0.610 & 0.488 & 0.453 & $0.414 * * *$ \\
\hline Campus Exposure to & -0.018 & 1.184 & 0.700 & -0.575 \\
\hline Down-and-Up Transfers & 1.426 & 1.557 & 1.377 & 0.513 \\
\hline Campus Six-Year First-Time & & 0.256 & 0.193 & \\
\hline Fulltime Graduation Rate & & $0.113 * *$ & $0.100^{*}$ & \\
\hline \multirow[t]{2}{*}{ Age } & -0.005 & -0.005 & -0.005 & -0.006 \\
\hline & $0.001^{* * *}$ & $0.001^{* * *}$ & $0.001 * * *$ & $0.001 * * *$ \\
\hline \multirow{2}{*}{ Female } & 0.021 & 0.021 & 0.023 & 0.027 \\
\hline & $0.006 * * *$ & $0.006 * * *$ & $0.006 * * *$ & $0.007 * * *$ \\
\hline \multirow[t]{2}{*}{ Black } & -0.042 & -0.038 & -0.043 & -0.054 \\
\hline & $0.015^{* *}$ & $0.015 * *$ & $0.016 * *$ & $0.023 * *$ \\
\hline \multirow[t]{2}{*}{ Hispanic } & -0.044 & -0.041 & -0.040 & -0.051 \\
\hline & $0.015 * * *$ & $0.016 * *$ & $0.015 * *$ & $0.022 * *$ \\
\hline \multirow[t]{2}{*}{ Asian } & 0.047 & 0.047 & 0.046 & 0.052 \\
\hline & $0.022 * *$ & $0.022 * *$ & $0.020 * *$ & $0.025^{* *}$ \\
\hline \multirow[t]{2}{*}{ Native American } & -0.011 & -0.008 & -0.007 & -0.016 \\
\hline & 0.022 & 0.022 & 0.022 & 0.051 \\
\hline \multirow[t]{2}{*}{ Nonresident Alien } & 0.086 & 0.087 & 0.083 & 0.170 \\
\hline & 0.070 & 0.071 & 0.075 & $0.084 * *$ \\
\hline \multirow[t]{2}{*}{ Missing Race } & -0.044 & -0.042 & -0.042 & -0.072 \\
\hline & $0.018 * *$ & $0.019 * *$ & $0.019 * *$ & $0.020 * * *$ \\
\hline \multirow[t]{2}{*}{ Earned AA } & -0.026 & -0.026 & -0.023 & -0.025 \\
\hline & $0.011 * *$ & $0.011^{* *}$ & $0.011 * *$ & $0.011^{* *}$ \\
\hline \multirow[t]{2}{*}{ Earned AS } & -0.014 & -0.014 & -0.013 & -0.005 \\
\hline & 0.011 & 0.010 & $0.008^{*}$ & 0.009 \\
\hline \multirow[t]{2}{*}{ Earned AAS/AOS } & -0.039 & -0.038 & -0.046 & -0.036 \\
\hline & $0.010^{* * *}$ & $0.010^{* * *}$ & $0.009 * * *$ & $0.011^{* * *}$ \\
\hline \multirow[t]{2}{*}{ Earned Certificate/Diploma } & -0.018 & -0.021 & -0.026 & -0.009 \\
\hline & 0.024 & 0.024 & 0.022 & 0.039 \\
\hline
\end{tabular}

(continued on next page) 
Table 3 (continued)

\begin{tabular}{lrrrr} 
& $\mathbf{1}$ & $\mathbf{2}$ & $\mathbf{3}$ & $\mathbf{4}$ \\
Fall & -0.022 & -0.022 & -0.023 & -0.012 \\
Time to Rising Junior & $0.005^{* * *}$ & $0.005^{* * *}$ & $0.005^{* * *}$ & -0.008 \\
& -0.217 & -0.215 & -0.214 & -0.196 \\
Lateral Transfers & $0.005^{* * *}$ & $0.005^{* * *}$ & $0.005^{* * *}$ & $0.005^{* * *}$ \\
& 0.027 & 0.027 & 0.029 & 0.001 \\
\hline Credits Accumulated & 0.024 & 0.024 & 0.024 & 0.040 \\
\hline & 0.001 & 0.001 & 0.000 & 0.001 \\
Missing Credits Accumulated & 0.000 & 0.000 & 0.000 & $0.000^{* *}$ \\
& -0.024 & -0.021 & -0.020 & -0.027 \\
GPA & 0.022 & 0.022 & 0.023 & 0.022 \\
& 0.133 & 0.131 & 0.129 & 0.122 \\
Missing GPA & $0.007^{* * *}$ & $0.007 * * *$ & $0.007 * * *$ & $0.008 * * *$ \\
& 0.323 & 0.319 & 0.316 & 0.300 \\
Fulltime & $0.025^{* * *}$ & $0.024^{* * *}$ & $0.023^{* * *}$ & $0.025 * * *$ \\
First-Time Fulltime & 0.220 & 0.217 & 0.207 & -0.006 \\
& $0.016^{* * *}$ & $0.016^{* * *}$ & $0.014^{* * *}$ & 0.194 \\
Distance from 2yr Campus & -0.034 & -0.032 & -0.032 & -0.018 \\
& $0.010^{* * *}$ & $0.010^{* * *}$ & $0.011^{* * *}$ & 0.012 \\
Attended Nearest 4yr & 0.001 & 0.001 & 0.001 & 0.000 \\
Campus to 2yr Campus & $0.001 *$ & 0.001 & 0.001 & 0.001 \\
Observations & -0.023 & -0.024 & -0.028 & -0.022 \\
R-squared & $0.013^{*}$ & $0.013^{*}$ & $0.011^{* *}$ & $0.011^{* *}$ \\
Controls for Field-of-Study & & & & \\
& 29,989 & 29,989 & 29,989 & 19,262 \\
& 0.243 & 0.244 & 0.251 & 0.186 \\
& No & No & Yes & Yes
\end{tabular}


Table 4

Coefficient on Campus-Level Exposure to Four-Term Transfers

All Cross-Section Results Control for Campus Six-Year Baccalaureate Rate

Robust standard errors

* significant at $10 \%$; ** significant at $5 \%$; *** significant at $1 \%$

$\underline{\text { Panel A: Dependent Variable is Six-Year Baccalaureate }}$

Field-of-Study Fixed Effects

Includes Unaffiliated Students

1. All

2. Omitting Transfers to Four-Year

Technical Colleges

3. Omitting Transfers To or From

Technical Colleges

\begin{tabular}{|c|c|c|c|c|c|}
\hline \multicolumn{3}{|c|}{ Cross-Section } & \multicolumn{3}{|c|}{ Panel } \\
\hline 1 & 2 & 3 & 4 & 5 & 6 \\
\hline No & Yes & No & Yes & Yes & Yes \\
\hline Yes & Yes & No & No & Yes & No \\
\hline 127 & 0.092 & -0.036 & -0.043 & -0.204 & -0.182 \\
\hline 140 & 0.125 & 0.119 & 0.104 & 0.133 & 0.135 \\
\hline 0.208 & 0.152 & 0.052 & -0.013 & -0.181 & -0.134 \\
\hline 176 & 0.156 & 0.149 & 0.131 & 0.139 & 0.137 \\
\hline 251 & 0.189 & 0.089 & 0.014 & -0.255 & -0.160 \\
\hline 186 & 0.168 & 0.164 & 0.144 & $0.152 *$ & $0.14 t$ \\
\hline
\end{tabular}

$\underline{\text { Panel B: Dependent Variable is Eight-Year Baccalaureate }}$

Field-of-Study Fixed Effects

Includes Unaffiliated Students

4. All

5. Omitting Transfers to Four-Year

Technical Colleges

6. Omitting Transfers To or From

Technical Colleges

$\begin{array}{rr}1 & \mathbf{2} \\ \text { No } & \text { Yes }\end{array}$

Yes Yes

$0.228 \quad 0.221$

$0.165 \quad 0.144$

0.043

0.114

0.291

0.280

0.101

0.119

$0.179 \quad 0.148 *$

0.333

0.310

$0.188^{*}$

$0.151^{*}$

0.145

0.133

0.118

$0.112 \quad 0.182$

0.093

0.107

$-0.136-0.126$

$0.161 \quad 0.165$

$\begin{array}{ll}-0.292 & -0.217\end{array}$

$0.182 \quad 0.187$ 
Table 5

Coefficient on Department-Level Exposure to Four-Term Transfers

Robust standard errors

* significant at $10 \%$; ** significant at $5 \%$; *** significant at $1 \%$

1. Four-Term Transfers

2. Natives

Campus Fixed Effects

Field-of-Study Fixed Effects

Panel (Department Fixed Effects)
1

$\begin{array}{llll}0.058 & 0.027 & -0.147 & 0.058\end{array}$

0.047

0.043

$0.051^{* * *}$

0.062

$\begin{array}{rrrr}0.095 & 0.100 & 0.000 & -0.052 \\ 0.044^{* *} & 0.037^{* * *} & 0.038 & 0.034\end{array}$

No

No

Yes

Yes

Yes

No

Yes

Yes

Yes 
Table 6a

Coefficient on Department-Level Exposure to Four-Term Transfers

Estimations on Population of Four-Term Transfers

Including Controls for Campus and Field-of-Study Fixed Effects

Robust standard errors

* significant at $10 \%$; ** significant at $5 \%$; *** significant at $1 \%$

Panel A: Dependent Variable is Six-Year Baccalaureate

Cross-Section

Includes Unaffiliated Students

Yes

1

No

1. All

$-0.147-0.197$

$0.051 * * * \quad 0.068 * * *$

2. Omitting Transfers to Four-Year

Technical Colleges

$-0.141 \quad-0.183$
$0.051 * * *$

$0.051^{* * *} \quad 0.067 * * *$

3. Omitting Transfers To or From

$-0.162-0.203$

Technical Colleges

$0.055 * * * \quad 0.071 * * *$

Panel

Yes No

$3 \quad 4$

$0.058 \quad 0.075$

$0.062 \quad 0.073$

$0.088 \quad 0.114$

$0.064 \quad 0.075$

$\begin{array}{ll}0.123 & 0.165\end{array}$

$0.069 * \quad 0.079 * *$

Panel B: Dependent Variable is Eight-Year Baccalaureate

Cross-Section

Includes Unaffiliated Students

4. All

Yes

1

No

$-0.113$

$0.059 *$

$-0.164$

$0.070^{* *}$

5. Omitting Transfers to Four-Year

$-0.098$

$-0.141$

Technical Colleges

$0.058 *$

$0.068 * *$

Panel

Yes

No

$3 \quad 4$

6. Omitting Transfers to or from

Technical Colleges

$-0.126$

$-0.175$

$0.063 * *$

$0.072 * *$

0.124

0.142

$0.056 * * \quad 0.069 * *$

$0.146 \quad 0.167$

$0.059 * * \quad 0.074 * *$

$0.186 \quad 0.191$

$0.066^{* * *} \quad 0.080^{* *}$ 
Table 6b

Coefficient on Department-Level Exposure to Four-Term Transfers

Estimations on Population of Natives

Including Controls for Campus and Field-of-Study Fixed Effects

Robust standard errors

* significant at $10 \%$; ${ }^{* *}$ significant at $5 \%$; *** significant at $1 \%$

Panel A: Dependent Variable is Six-Year Baccalaureate

Cross-Section

Includes Unaffiliated Students

1. All

2. Omitting Technical Colleges Natives
Yes

$\begin{array}{rr}1 & 2 \\ 0.000 & -0.006\end{array}$

$0.038 \quad 0.050$

$-0.001 \quad-0.006$

0.038
Panel

Yes No

$3 \quad 4$

$-0.052 \quad-0.075$

$0.035 \quad 0.037^{* *}$

$-0.050 \quad-0.075$

$0.035 \quad 0.038 * *$

Panel B: Dependent Variable is Eight-Year Baccalaureate

Includes Unaffiliated Students

3. All

4. Omitting Technical Colleges Natives

\section{Cross-Section}

Yes

1

$-0.010$

0.036

$-0.009$

0.036
Panel

Yes

3

No

$\begin{array}{ll}-0.087 & -0.117\end{array}$

$0.039 * * \quad 0.045^{* * *}$

$\begin{array}{ll}-0.074 & -0.099\end{array}$

$0.039 * \quad 0.045^{* *}$ 
Appendix Table 1

Definitions of Academic-Related Variables

1. Campus (Department) Exposure to Four-Term Transfers (Early Transfers, Down-and-Up Transfers) Share of other students at campus (department) that are four-term transfers (early transfers, down-and-up transfers).

2. Campus Six-Year First-Time Fulltime Graduation Rate

Percentage of first-time fulltime students at a four-year campus that receive a SUNY baccalaureate within 6 years.

3. Earned AA (AS, AAS/AOS, Certificate/Diploma)

Dummy Variable equal to 1 if rising junior transfer has earned an AA degree (AS, AAS/AOS, Certificate/ Diploma) from a SUNY community college.

4. Fall

Dummy Variable equal to 1 if rising junior is a rising junior in a fall semester.

5. Time to Rising Junior

Calendar years between initial SUNY enrollment and rising junior status. Measured in half-year increments.

6. Lateral Transfers

Number of times a rising junior has transferred from an institution of one level to an institution of the same level, e.g. transferring from one four-year college to another four-year college.

7. Credits Accumulated

Credits a rising junior has accumulated towards a baccalaureate degree.

8. GPA

Grade Point Average.

9. Fulltime

Dummy variable equal to 1 if rising junior is enrolled fulltime.

10. First-Time Fulltime

Dummy variable equal to 1 if rising junior was enrolled fulltime during his first semester at SUNY.

11. Distance from 2yr Campus

Distance, in miles, from transfer's community college campus to his four-year college campus.

12. Attended Nearest 4 yr Campus to 2yr Campus

Dummy variable equal to 1 if transfer attended four-year campus closest to his community college. (See also Footnote 13.) 